\title{
Green synthesis of silver nanoparticles from extracts of Pechuel-loeschea leubnitziae: their anti- proliferative activity against the U87 cell line
}

\author{
Motshewa Justina Mofolo, Pauline Kadhila, Kazhila Croffat Chinsembu, \\ Samson Mashele \& Mamello Sekhoacha
}

To cite this article: Motshewa Justina Mofolo, Pauline Kadhila, Kazhila Croffat Chinsembu, Samson Mashele \& Mamello Sekhoacha (2020) Green synthesis of silver nanoparticles from extracts of Pechuel-loeschea leubnitziae: their anti-proliferative activity against the U87 cell line, Inorganic and Nano-Metal Chemistry, 50:10, 949-955, DOI: 10.1080/24701556.2020.1729191

To link to this article: https://doi.org/10.1080/24701556.2020.1729191

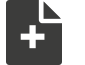

View supplementary material $₫$

Published online: 04 Mar 2020.

Submit your article to this journal $\pi$

II Article views: 161

Q View related articles $\sqsubset$

View Crossmark data \lceil

Citing articles: 2 View citing articles $匚$ 


\title{
Green synthesis of silver nanoparticles from extracts of Pechuel-loeschea leubnitziae: their anti-proliferative activity against the U87 cell line
}

\author{
Motshewa Justina Mofolo ${ }^{\mathrm{a}}$, Pauline Kadhilab, Kazhila Croffat Chinsembu ${ }^{\mathrm{b}}$, Samson Mashele ${ }^{\mathrm{a}}$, and \\ Mamello Sekhoachac

\begin{abstract}
aUnit for drug discovery Research, Department of Health Science, Faculty of Health and Environmental Sciences, Central University of Technology, Free State, Bloemfontein, South Africa; ${ }^{b}$ Department of Biological Science, University of Namibia, Windhoek, Namibia; 'Department of Pharmacology, Faculty of Health Science, University of the Free State, Bloemfontein, South Africa
\end{abstract}

\begin{abstract}
The application of green chemistry for the synthesis of nanoparticles is said to be environmentally friendly and cost efficient. The paper reports on the cell anti-proliferative activity of Pechuelloeschea leubnitziae, synthesis of silver nanoparticles using $P$. leubnitziae and characterization. The UV-vis spectroscopy confirmed presence of a peak at $400 \mathrm{~nm}$, and Fourier-transform infrared spectroscopy confirmed the presence of peaks from $700-4000 \mathrm{~cm}^{-1}$ correlating to AgNPs. Presence of silver, carbon and oxygen was confirmed by X-ray photoelectron spectroscopy and Energydispersive X-ray spectroscopy. Transmission electron microscopy showed a uniform spherical particle in the size of $100 \mathrm{~nm}$, and scanning electron microscope showed spherical particles at a magnification of $100 \mu \mathrm{m}$. The extracts and the synthesized AgNPs were tested for cytotoxicity and anti-cancer activity against the Vero and U87 glioma cell lines. The results for both cell lines indicated that dichloromethane extract and AgNPs were cytotoxic and had potential anticancer properties.
\end{abstract}

\section{ARTICLE HISTORY}

Received 17 October 2019

Accepted 2 February 2020

\section{KEYWORDS}

Inhibition; U87 glioma;

Cytotoxicity; Silver

nanoparticles

\section{Introduction}

Nanotechnology, which involves the synthesis of matter in the rage of 1-100 nm, has advanced the synthesis of $\mathrm{Ag}$ with a variety of unique morphologies and characteristics at the nanoscale. ${ }^{[1]}$ AgNPs, instead of bulky metallic Ag, are considered suitable theranostic agents in cancer research, due to their peculiar biological properties and anticancer properties against some cancer cells, which include human glioblastoma cells U251 and MDA-MB-231 human breast cancer cells. ${ }^{[2-4]}$ A study done by Asharani and colleagues showed that non-cytotoxic doses of AgNPs can induce DNA damage and enhance apoptosis in glioblastoma multiforme cells. ${ }^{[3]}$ Furthermore, when AgNPs were injected in a chicken embryo implanted with U87 glioma cells, anti-proliferation was observed. ${ }^{[5]}$ AgNPs have also been applied in the synthesis of consumer products, coating of medical devices, cosmetics and treatment of diseases. ${ }^{[6]}$ A variety of methods such as physical, chemical, and biological have been used successfully to produce AgNPs. ${ }^{[7]}$ However, for methods such as physical and chemical, the release of hazardous byproducts into the environment and cost effects have been shown to be amongst the many challenges encountered while applying these methods. ${ }^{[8]}$ Thus it has become quite important for the study to exploit more environmentally friendly, cheap and easy methods for the synthesis of AgNPs. ${ }^{[9]}$ In this study, the green synthesis using plant extract was applied for the synthesis of AgNPs.

Naturally, plants synthesize secondary metabolites which they use as a defense mechanisms against predators and diseases. ${ }^{[10]}$ These metabolites are utilized by humans as alternative treatments for diseases such as diabetes, inflammation and cancer. ${ }^{[1]}$ In nanomedicine, the majority of the secondary metabolites have been identified to reduce metallic precursor salts to metal NPs; the plant extract is mixed with the metal salt and dissolved in distilled water at room temperature, and a change in color is observed for the formation of AgNPs. ${ }^{[12,13]}$ In a study done by Amin and colleagues, functional groups of phenolic and alkaloids were shown to be responsible for the reduction of metals to metallic nanoparticles. ${ }^{[14]}$

The selected plant, $P$. leubnitziae is a chamaephyte belonging to the family Asteraceae, and is indigenous to Southern Africa. ${ }^{[15]}$ It is found in areas that include Botswana, southern Angola, Namibia, Swaziland, Zimbabwe and northern South Africa. ${ }^{[16]} P$. leubnitziae is one of the medicinal plants used widely in Southern Africa. Historically, the plant was used to treat gonorrhea, fever, colds and chest infections, and stomach pains. Other uses of the plant include the treatment of measles, the disinfection 
of open wounds, and fighting intestinal bacteria. ${ }^{[17-20]}$ The phytochemical analysis of the plant revealed the presence of phytochemicals such as saponins, anthraquinones, flavonoids, and polyphenols, and further studies done by Ndongo showed that plant had antioxidants such as phenols. ${ }^{[21,22]}$ However, none of the reported studies focused on the synthesis of nanoparticles using this plant. The project aimed to investigate the cytotoxicity of $P$. leubnitziae against the $\mathrm{CHO}$ cell line, the synthesis of AgNPs using the plant extracts and to determine the efficacy of the AgNPs against the U87 glioma cell line.

\section{Methodology}

The powdered roots part of the P. leubnitziae was donated by Dr Pauline Kadhila from the University of Namibia. The plant's voucher number is 13 and its identity was confirmed by the curator from the National Herbarium at the National Botanical Research Institute of Namibia. The material $(20 \mathrm{~g})$ was extracted sequentially, using $100 \mathrm{~mL}$ of organic solvents in their decreasing order of polarity; hexane, dichloromethane, and methanol. Extracts were concentrated using a rotary evaporator (Buchi, labotech Switzerland). The dried extracts were weighed and then refrigerated $\left(4^{\circ} \mathrm{C}\right)$ for future studies.

\section{Phytochemical analysis}

The phytochemicals analysis of $P$. leubnitziae was carried out following the method done by Kadhila. ${ }^{[23]}$ Freshly prepared Liebermann-Burchard (LBr) reagent was used for the detection of terpenoids and saponins. The reagent was prepared by carefully adding $5 \mathrm{~mL}$ of concentrated $\mathrm{H}_{2} \mathrm{SO}_{4}$ to $50 \mathrm{~mL}$ of absolute ethanol on ice. The TLC plates were prepared and sprayed with $5-10 \mathrm{~mL}$ of $\mathrm{LBr}$ reagent, warmed at $100^{\circ} \mathrm{C}$ for 5 to 10 minutes. The anthraquinones and coumarins were evaluated using freshly prepared $\mathrm{KOH}$. The TLC plates were sprayed with $10 \mathrm{~mL}$ of a $10 \%(\mathrm{w} / \mathrm{v}) \mathrm{KOH}$ in $96 \%$ ethanolic solution and dried. The flavonoids were detected using aluminum chloride. Each TLC plate was sprayed with $5-10 \mathrm{~mL}$ of $1 \%(\mathrm{w} / \mathrm{v}) \mathrm{AlCl}_{3}$ in $95 \%$ ethanolic solution. The Dragendorff reagent was prepared and used for the detection of alkaloids. The reagent was prepared by dissolving $8.00 \mathrm{~g}$ of $\mathrm{KI}$ in $20 \mathrm{~mL}$ of distilled water. This solution was then added to a second solution containing $0.85 \mathrm{~g}$ of basic bismuth nitrate in $40 \mathrm{~mL}$ of distilled $\mathrm{H}_{2} \mathrm{O}$ and $10 \mathrm{~mL}$ of glacial acetic acid. The TLC plate was sprayed with $10 \mathrm{~mL}$ of the reagent. The phytochemicals were analyzed using a UV light at $365 \mathrm{~nm}$.

\section{Silver nanoparticle (AgNp) synthesis}

Silver nitrate $\left(\mathrm{AgNO}_{3}\right)$ was purchased from Sigma-Aldrich Chemicals, South Africa. Five grams $(5 \mathrm{~g})$ of $\mathrm{AgNO}_{3}(10 \mathrm{mM})$ and $1 \mathrm{~g}$ of methanol extract were dissolved in $100 \mathrm{~mL}$ of distilled water. The mixture was left on a magnetic stirrer overnight to favor the reduction of $\mathrm{AgNO}_{3}$ to $\mathrm{Ag}^{+}$ions at $60^{\circ} \mathrm{C}$ and further dried in the oven at $70^{\circ} \mathrm{C} .{ }^{[24]}$ The dry sample was stored in closed vials at room temperature for future use.

\section{Characterization of silver nanoparticles}

Preliminary characterization of the AgNps was carried out using a PerkinElmer Lambda 950 UV/Vis Spectrophotometer. The AgNp sample was annealed in an oxygen atmosphere at $500^{\circ} \mathrm{C}$ temperatures. The structural property of the NPs was investigated by X-ray diffraction (XRD, Bruker D8. The X-ray source was $3 \mathrm{~kW}$ with a $\mathrm{Cu}$ target; high-resolution $\mathrm{XRD}$ patterns were measured using a scintillation counter $(\lambda=1.5406 \AA)$. The XRD data were collected over a $2 \Theta$ range of $15^{\circ}-80^{\circ}$ with steps of $0.034^{\circ}$. The AgNPs solution was dried, and a pellet was used for FTIR measurements. The spectrum was recorded in the range of $4000-400 \mathrm{~cm}^{-1}$ using a Thermo Nicolet Nexus 670 spectrometer in the diffuse reflectance mode operating at a resolution of $4 \mathrm{~cm}^{-1}$. ${ }^{25]}$

Transmission electron microscopy (Philips 100 transmission electron microscope) was used to obtain highresolution images of the NPs. The morphology of NPs was investigated by scanning electron microscopy, JEOL JEM 2010 UHR equipped with a Gatan Imaging Filter, with a $15-\mathrm{eV}$ window and a 794 slow-scan CCD camera, operating at $2.00 \mathrm{kV}$. X-ray photoelectron spectroscopy (XPS) was performed at $100 \mu \mathrm{m}$ diameter monochromatic $\mathrm{Al} \mathrm{K} \alpha$ x-ray beam $(\mathrm{h} \nu=1486.6 \mathrm{eV})$ generated by a $25 \mathrm{~W}$ and $15 \mathrm{kV}$ electron beam. The pass energy was set to $11 \mathrm{eV}$ to give an analyzer resolution $\leq 0.5 \mathrm{eV}$. The Multipack version 9 software was used to analyze the spectra to identify the chemical compounds and their electronic states using GaussianLorentz fits. Furthermore, the compounds present were identified using SEM-EDAX (JEOL JEM 2010 UHR).

\section{Cell anti-proliferation assay}

The cytotoxicity of the plant extracts and synthesized AgNPs were assayed by MTT against the U87 glioma and Vero cell line. Briefly, the cells were seeded in a 96-well plate at a concentration of $1 \times 10^{5}$ cells $/ \mathrm{mL}$, provided with DMEM supplemented with $10 \%$ Fetal Bovine Serum (FBS) and left in an incubator at $37^{\circ} \mathrm{C}$ for 24 hours to allow attachment. The cells were treated with concentrations of $100-0.001 \mu \mathrm{g} / \mathrm{mL}$ of the test samples. After 48 hours of incubation, $25 \mu \mathrm{L}$ of MTT was added to all the wells and the plate was incubated for a further 4 hours. The plate was developed by adding $100 \mu \mathrm{L}$ of DMSO and absorbance was measured at $540 \mathrm{~nm}$ using a spectrophotometer (GO Multi- skan).

\section{Statistical analysis}

The results for MTT assay were analyzed using Ms Excel and $\mathrm{IC}_{50}$ calculated using Prism GraphPad Prism version 8.0 software for Windows. The assay was done in triplicates. 


\section{Results}

\section{Phytochemical analysis}

The presence of terpenoids and saponins were confirmed by a brown zone under UV light at $365 \mathrm{~nm}$, dark-brown in visible light, gray zone in UV $365 \mathrm{~nm}$, and a weak gray in visible light. The anthraquinones and coumarins compounds were confirmed by the presence of a yellow zone on the TLC plate under the UV and visible light. Flavonoids were confirmed by the presence of a blue, green and purple zone on the TLC plate. The alkaloids were further confirmed by the presence of orange to red color and yellow zone (supplementary table 1).

\section{UV-vis spectroscopy and XRD analysis}

The preliminary confirmation for the formation of AgNPs was observed through the color change from clear brown to dark-brown under visible light. The characterization of AgNPs was monitored using the UV-vis. Results showed the presence of a peak at $400 \mathrm{~nm}$, which was assigned to the presence of AgNPs and the minute presence of a peak at $350 \mathrm{~nm}$, was attributed to the presence of AgO in the sample (Figure 1). Further characterization of Ag was confirmed by $\mathrm{XRD}$ in Figure 2. The results showed prominent peaks at $2 \Theta=40.0,43.43,64.55$ and $77.44^{\circ}$, which correspond with the (111), (200), (220) and (311) planes, respectively. These observed planes indicate that AgNPs using the plant $P$. leubnitziae had crystalline nature. More peaks which include $2 \Theta=$ 19.56, 21.68, 24.26, 29.57, 32.76 and $35.44^{\circ}$, were detected in the sample and attributed to the presence of $\mathrm{AgNO}_{3}$ (Figure 2). Furthermore, impurities of $\mathrm{AgO}$ were detected at peaks $2 \Theta=54.6$ and $31.8^{\circ}$

\section{Fourier-transform infrared spectroscopy (FTIR) spectral analysis}

The FTIR spectra results showed possible functional groups for the reduction of $\mathrm{AgNO}_{3}$ by P. leubnitziae (Figure 3). A band at about $2991 \mathrm{~cm}^{-1}$ was attributed to stretching of $\mathrm{C}-\mathrm{H}$ alkane and the $\mathrm{O}-\mathrm{H}$ stretch of carboxylic acids. The

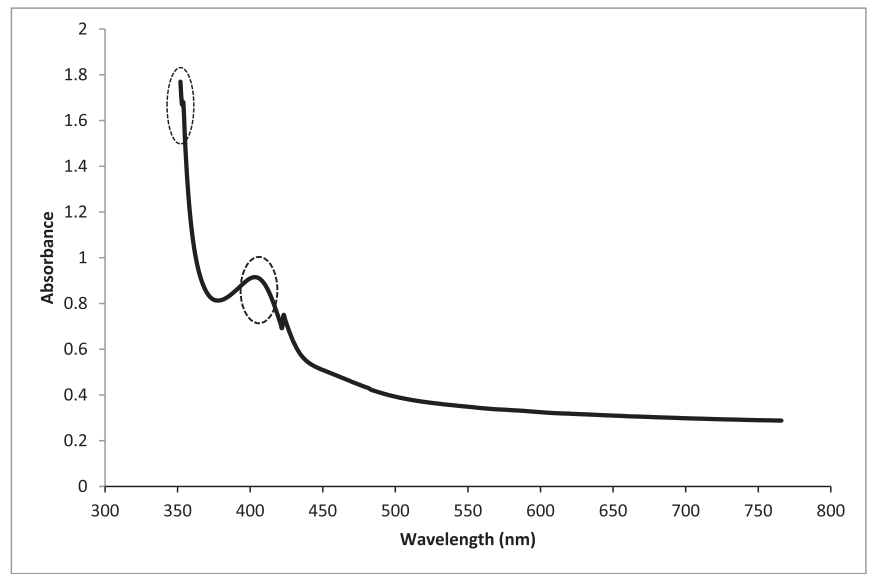

Figure 1. The Uv-vis absorption spectra of AgNPs synthesized using the methanol extract of $P$. leubnitziae. presence of band at $2354 \mathrm{~cm}^{-1}$ was correlated to the possible presence of the $\mathrm{C}=\mathrm{C}$ group, presence of alkynes, $\mathrm{N}-\mathrm{C}$ and $\mathrm{N}=\mathrm{C}$ groups. Furthermore, observed bands at 1774$1753 \mathrm{~cm}^{-1}$ can be attributed to the presence of $\mathrm{C}=\mathrm{O}$. The band at $1593 \mathrm{~cm}^{-1}$ was an indicator of the bending of $\mathrm{O}-\mathrm{H}$, which indicates carboxylate. The weak bands at $1278 \mathrm{~cm}^{-1}$ was assigned to $\mathrm{C}-\mathrm{N}$ stretching and confirmed the presence of carboxylic acid group. The bands at $1040-732 \mathrm{~cm}^{-1}$ were attributed to the presence of $=\mathrm{CH}$ found in aromatic compounds of plant extracts and bands at $599 \mathrm{~cm}^{-1}$ are attributed to the AgNPs.

\section{Transmission electron microscopy (TEM) and scanning electron microscope (SEM)}

Figure 4a shows the morphology of the synthesized AgNPs observed at $100 \mathrm{~nm}$ using the transmission electron microscopy. The shape of the NPs appeared spherical and opaque at different locations of the grid, indicating that the NPs are stable (Figure $4 \mathrm{a}$ ) and uniform in the size of $100 \mathrm{~nm}$, with no visible aggregations or agglomeration Furthermore, the morphology of the nanoparticle was observed using the scanning electron microscope at the magnification of $100 \mu \mathrm{m}$ Figure 4b. The morphology of the AgNPs was observed to be a uniform spherical shape of aggregated nanoparticles (Figure 4 b), which correlated with the observed morphology under the transmission electron microscopy.

\section{The X-ray photoelectron spectroscopy (XPS) results}

The XPS results revealed the presence of $\mathrm{Ag}, \mathrm{C}$ and $\mathrm{O}$ atoms according to their binding energies as shown in Figure 5. The peaks were shifted according to $\mathrm{C} 1 \mathrm{~s}-284.5 \mathrm{eV}$. The results indicate low peaks of $\mathrm{C}$ and $\mathrm{O}$ and high peaks of $\mathrm{Ag}$. In general, the presence of $\mathrm{C} 1 \mathrm{~s}$ and $\mathrm{O} 1 \mathrm{~s}$ peaks are indicative of high and low electrochemical activity regions, respectively. The most prominent signal in the XPS spectrum, Ag3d, consists of two spin-orbit components at 368 $(\mathrm{Ag} 3 \mathrm{~d} 5)$ and $374(\mathrm{Ag} 3 \mathrm{~d} 3) \mathrm{eV}$, which are separated by $\sim 6.0 \mathrm{eV}$ binding energy (Figure 6). These observed results are correlated with the standard Ag3d binding energies, $3 \mathrm{~d} 5 / 2=368.3 \mathrm{eV}, \quad 3 \mathrm{~d} 3 / 2=374.3 \mathrm{eV}$ tabulated earlier, ${ }^{[26]}$ which are characteristic of $\mathrm{Ag}$. In each side of the $\mathrm{Ag} 3 \mathrm{~d} 5$

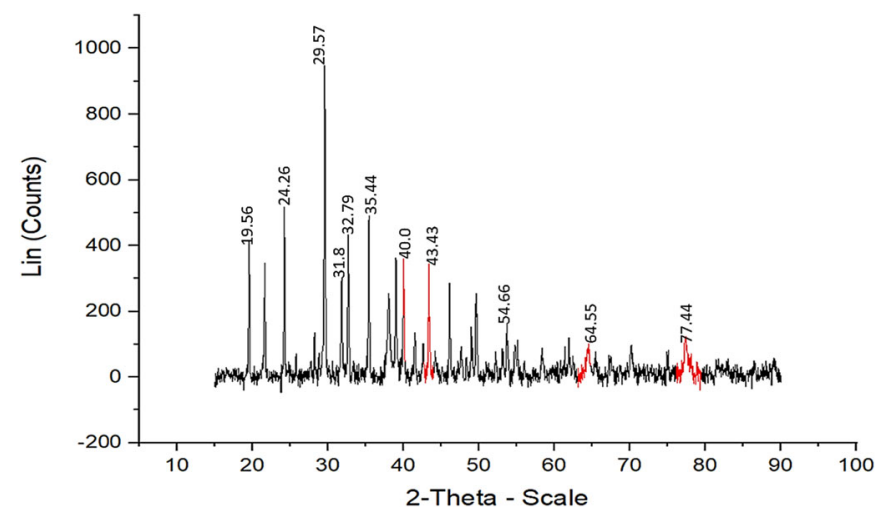

Figure 2. The XRD pattern of AgNPs synthesized with P. leubnitziae. The red peaks indicate AgNPs, while the black peaks show the presence of $\mathrm{AgNO}_{3}$. 


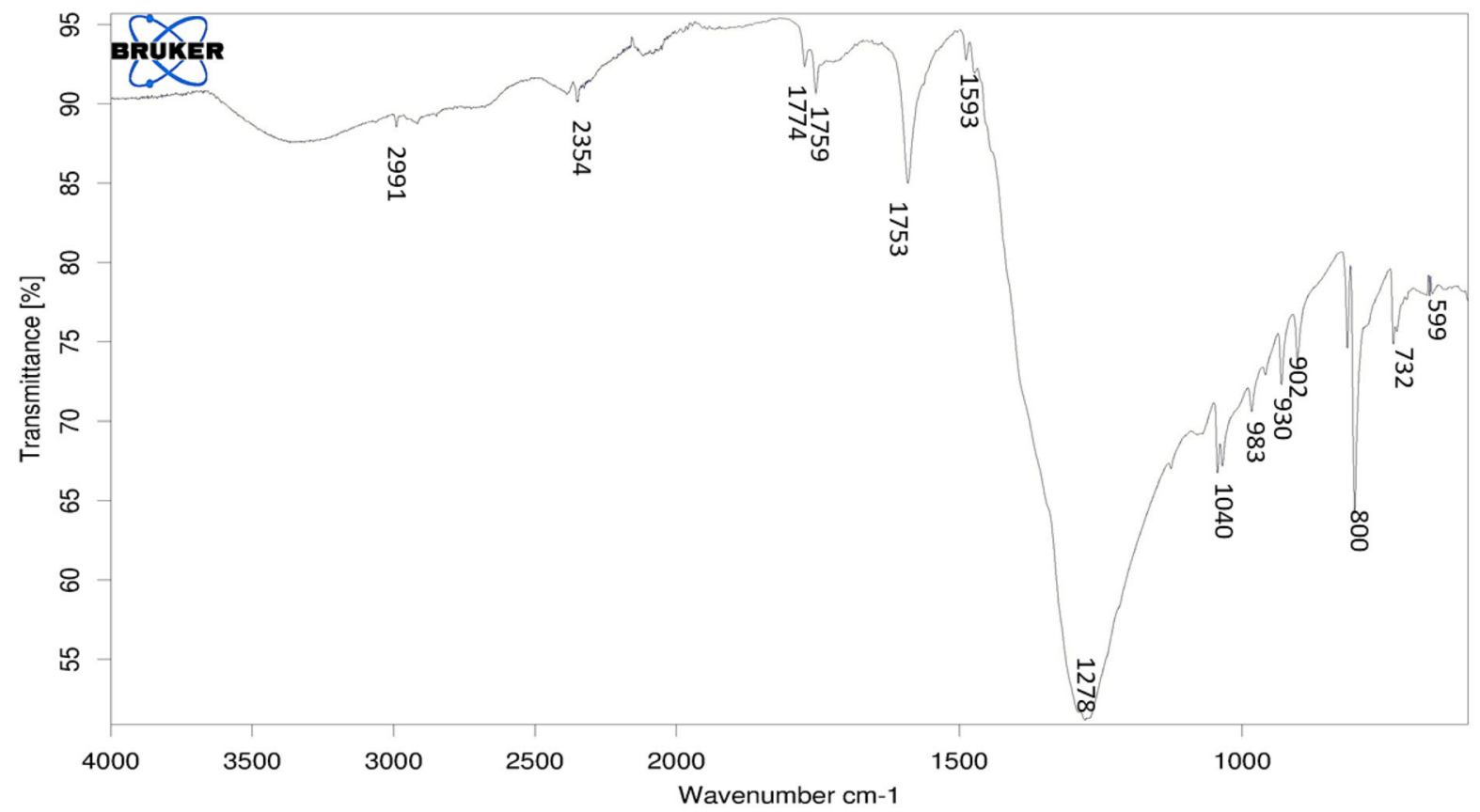

Figure 3. The FTIR results of the AgNPs synthesized using $P$. leubnitziae.

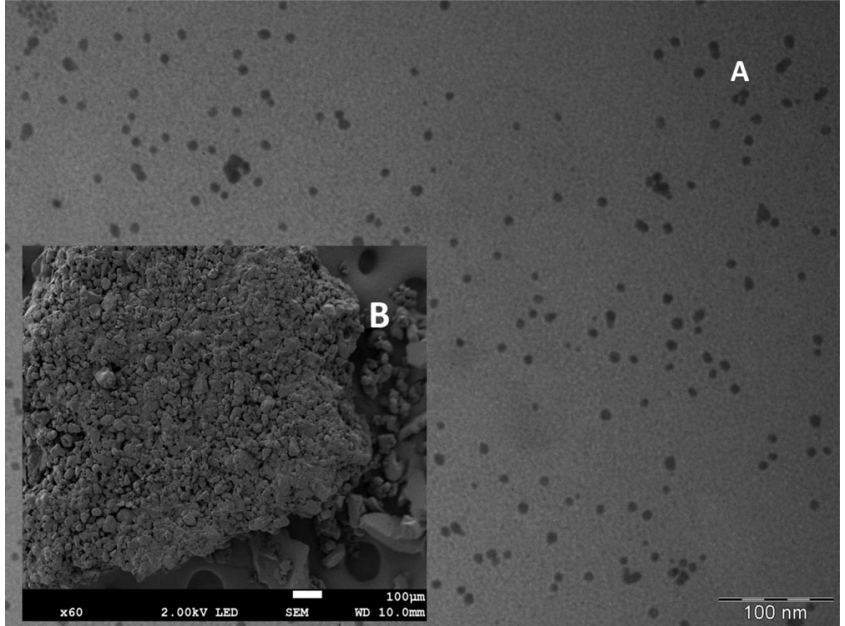

Figure 4. (A), the TEM results of AgNPs, observed at $100 \mathrm{~nm}$. (B) SEM results of AgNPs observed at $100 \mu \mathrm{m}$.

and $\mathrm{Ag} 3 \mathrm{~d} 3$, energy loss was observed at $366 \mathrm{eV}$ and $372 \mathrm{eV}$, respectively. When the samples were annealed, the peak positions showed no significant change; however, the intensities of the peak changed and indicated a change in the material at the surface. The binding energy of $\mathrm{O} 1 \mathrm{~s}$ was identified to be $532 \mathrm{eV}$ and that of C1s was indicated to be $285 \mathrm{eV}$ (Figure 6).

\section{EDAX analysis of silver NPs}

The AgNPs sample was further analyzed for the elementary composition using EDAX. In Figure 7, the horizontal axis represented the energy in $\mathrm{keV}$, while the vertical axis represented the X-ray counts. The results confirmed the presence of AgNPs and other elements such as; nitrogen, carbon and oxygen. The absorption of $\mathrm{Ag}$ was observed at $3 \mathrm{keV}$, which was in alignment with the literature. ${ }^{[27]}$

\section{The cell anti-proliferation results}

The cytotoxicity of 2 extracts, AgNPs and emetine were investigated against the Vero cell line (Figure 8). The growth inhibition activity of the cells was shown to be low for the concentrations of $0.001-0.1 \mu \mathrm{g} / \mathrm{mL}$ for all the test samples. The results indicated an overgrowth of the cells at a concentration of $0,001 \mu \mathrm{g} / \mathrm{mL}$ for the test samples; AgNPs, dichloromethane (DCM) and methanol $(\mathrm{MeOH})$. Furthermore, all samples showed activity at the concentration of $100 \mu \mathrm{g} / \mathrm{mL}$, while the growth inhibition activity of the NPs increased from $1-100 \mu \mathrm{g} / \mathrm{mL}$. The dichloromethane extract showed growth inhibition activity from $10-100 \mu \mathrm{g} / \mathrm{mL}$ (Figure 8 ).

Based on the obtained cytotoxicity results, the anticancer activity of the plant extracts, DCM, and AgNPs, was further investigated against the U87 cell line (Figure 9). The results revealed that, the DCM extract had inhibitory activities against the $\mathrm{U} 87$ glioma cell line with $\mathrm{IC}_{50}$ value in the range of $3.26-3.75 \mu \mathrm{g} / \mathrm{mL}$ as shown in Table 1. AgNPs exhibited an enhanced cell inhibitory effect, with $\mathrm{IC}_{50}$ values in the range of $0.64-0.71 \mu \mathrm{g} / \mathrm{mL}$, while emetine was used as the positive control for the study, and it had an $\mathrm{IC}_{50}$ in the range of $0.013 \mu \mathrm{g} / \mathrm{mL}$ (Table 1 ).

\section{Discussion}

Phytochemical analysis in this study showed the presence of terpenoids, saponins, anthraquinones, coumarins, flavonoids and alkaloids. The FTIR results of the AgNPs revealed peaks that, according to literature, are correlated to the presence of compounds such oil, fats, carbohydrate, phenolic, tannins and those identified in our studies: flavonoids and saponins as major functional groups for the formation of the AgNPs. ${ }^{[28]}$ When the plant extract and $\mathrm{AgNO}_{3}$ were mixed at room temperature, a change in color was observed, which occurred due to the reduction of $\mathrm{Ag}^{+}$ions to $\mathrm{Ag}$ by the 


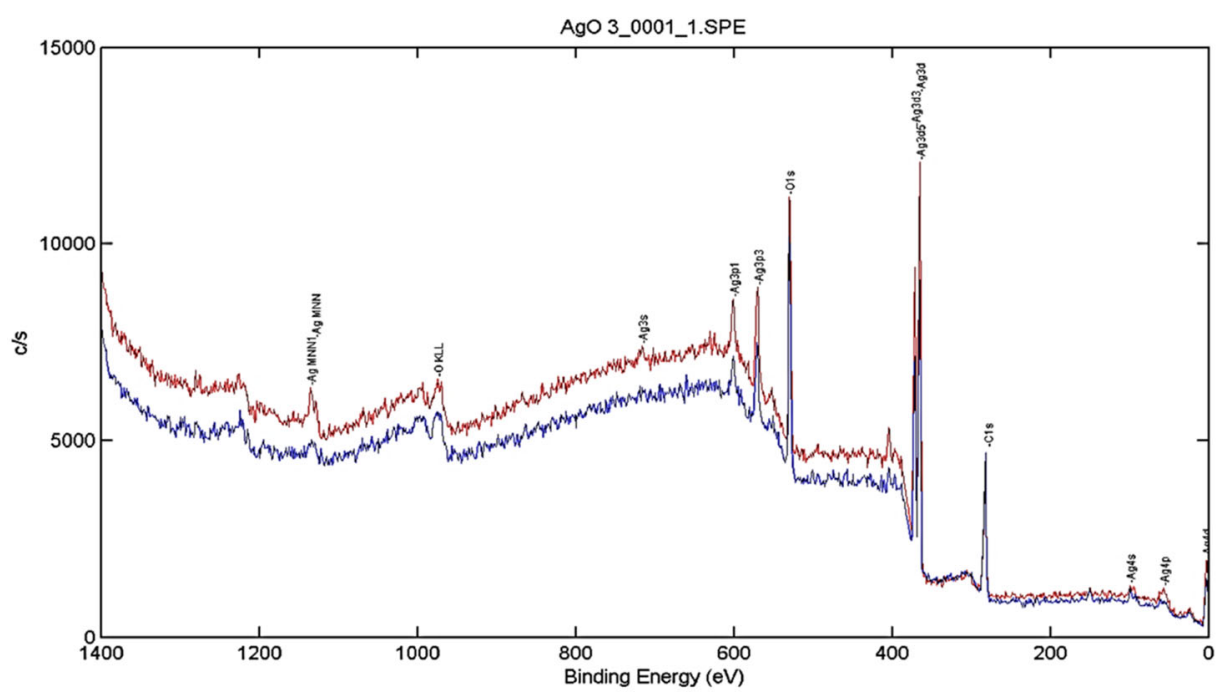

Figure 5. X-ray photoelectron spectroscopy (XPS) spectrum of AgNPs. The red line represents before annealing and the blue line represents after annealing of the sample.
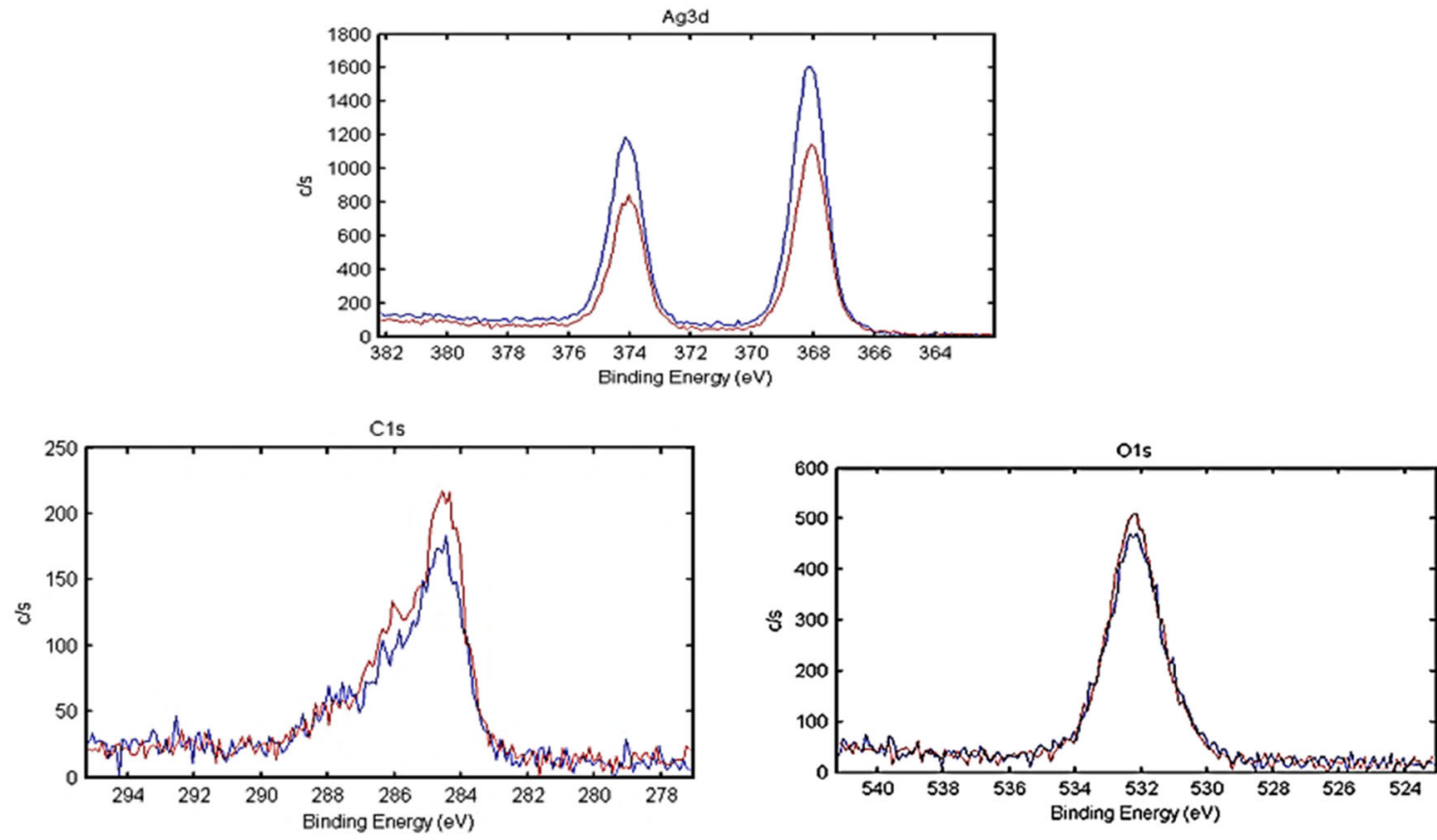

Figure 6. The XPS spectra of components present in the AgNPs sample. The red line represents before annealing and the blue line after annealing of sample.

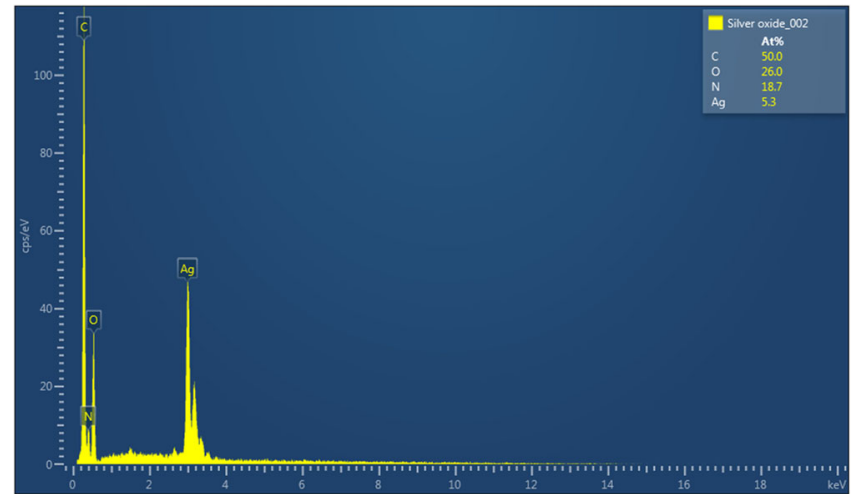

Figure 7. The EDAX spectrum showing peaks of elements present in the sample. Carbon (50\%), Oxygen (26\%), Nitrogen (18.7\%) and Silver (5.3\%) were detected. The organic elements could be from functional groups of the phytochemical components present in the plant.

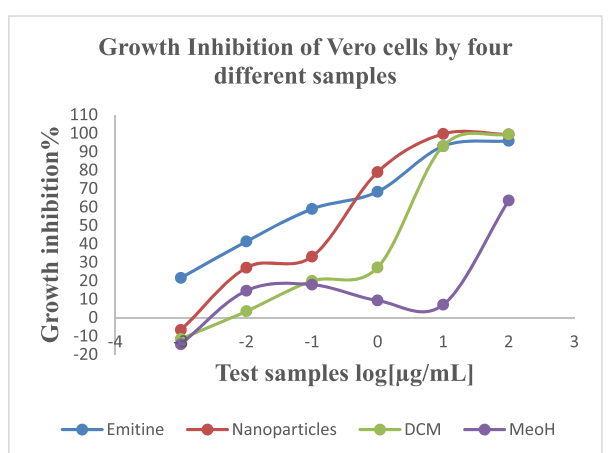

Figure 8. The growth inhibition of test samples against the Vero cell line, using the full dilution of the samples. 


\section{Growth inhibition of $U 87$ cells by extracts of P. leubnitziae}

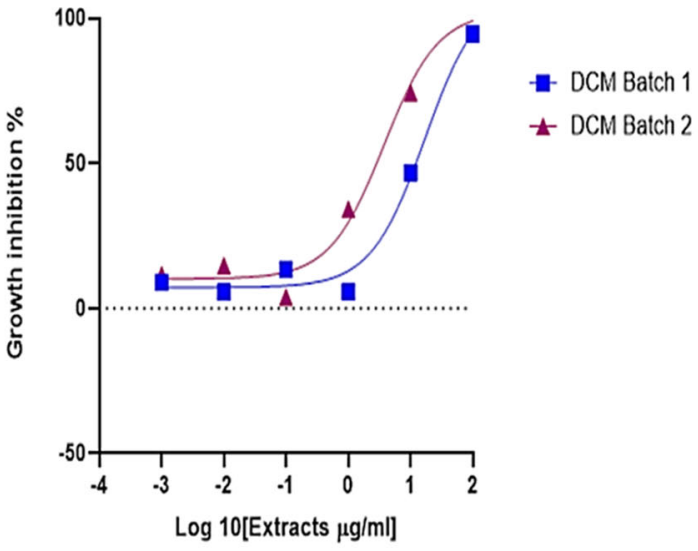

Growth inhibition of U87 cells by Silver Oxide nanoparticles.

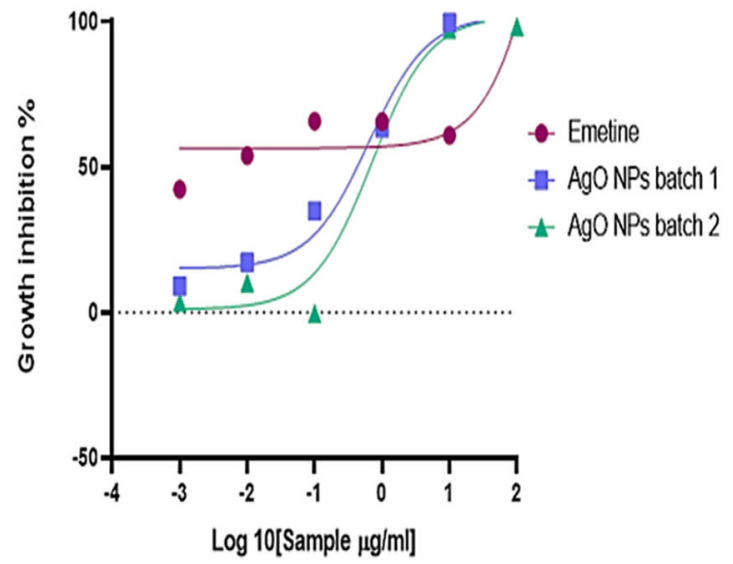

Figure 9. The cell growth inhibitory effects of test against the U87 cell line, a) batch $1=$ DCM extracts, batch $2=$ DCM from Namibia. b) Cytotoxicity drug emetine used as positive control; NPs synthesized using methanol extracts obtained from plant material collected in separate batches.

Table 1. The $\mathrm{IC}_{50}$ values of; dichloromethane $(\mathrm{DCM})$, AgNPs and emetine drug, against the U87 cells.

\begin{tabular}{lrrrrrr}
\hline & \multicolumn{2}{c}{ The plant extracts } & & & \multicolumn{2}{c}{ AgNPs } \\
\cline { 2 - 3 } \cline { 6 - 7 } & DCM batch 1 & DCM batch 2 & Emetine & Batch 1 & Batch 2 \\
\hline Log IC $\mathrm{C}_{50}$ & 0,5129 & 0,5724 & $-1,95$ & $-0,1954$ & $-0,1485$ \\
$\mathrm{IC}_{50}$ & 3,257 & 3,736 & 0,013 & 0,6377 & 0,7104 \\
R squared & 0,05491 & 0,8257 & 0,6902 & 0,9479 & 0,9301 \\
\hline
\end{tabular}

plant metabolites. This was further confirmed by UV-vis spectroscopy with a peak that was correlated to the formation of AgNPs aggregation, ${ }^{[29]}$ while XRD indicated the presence of peaks correlating to the face- cubic (fcc) crystal structure of metallic Ag. The AgNPs appeared aggregated when observed at a magnification of $100 \mu \mathrm{m}$ and this observation was in alignment with a study previously done by $\mathrm{Li}$ Kai et al, ${ }^{[30]}$ which demonstrated the aggregation of AgNPs at room temperature. The components identified while running XPS and EDAX confirmed the presence of $\mathrm{Ag}$ as part of the constituents in the sample, together with other constituents which are due to the plants' phytochemicals.

The cytotoxicity results suggest that the dichloromethane extract, which is known to extract low-polarity compounds, exhibited the highest inhibitory activity against both; Vero and U87 cell line, in contrast to the methanol extracts. Further investigation of the dichloromethane against the U87 cell line indicated the extract might have potential anticancer properties. In a study related to the plant $P$. leubnitziae, the dichloromethane was also shown to have in-vitro activity against Plasmodium falciparum. The activity was attributed to the presence of Xerantholide and was reported to exhibit antimalarial properties. ${ }^{[23]}$ It is therefore possible that this molecule is responsible for cell inhibitory activity observed in the dichloromethane extract against the U87 cell line. The synthesized NPs were shown to be concentration dependent, with higher inhibitory activity observed in U87 cells in contrast to the Vero cells. The increased inhibition of the AgNPs in comparison to the plant extract, against the U87 cells suggests that AgNPs have potential antiproliferative activities and can be considered a potent anticancer compound. ${ }^{[31]}$ The use of AgNPs in-vitro studies and the current study continue to show the toxicity of the AgNPs toward cancer cells, suggesting the importance of stabilizing the NPs for human consumption.

\section{Conclusion}

In summary, we have shown that there is scientific validation of use of $P$. leubnitziae as an anticancer medicinal plant. The plant has secondary metabolites that are able to reduce metal precursors. The results suggest that the dichloromethane extract and AgNPs synthesized with the methanol extract had cytotoxic activity against the U87 glioma cell line; however, the capping ability of the AgNPs is still yet to be understood.

\section{Acknowledgments}

We are thankful to Dr Bertrand Sone, Flow Process and Rheology Centre, Faculty of Engineering, Cape Peninsula University of Technology, Cape Town 8001, South Africa and Dr Ernie Langer, Faculty of Natural and Agricultural science, Chemistry, University of the Free State, Park West, Bloemfontein, South Africa, 9300 for assisting with the characterization of the nanoparticles.

\section{Funding}

We would like to thank the National Research Foundation (NRF), the Central University of Technology and University of the Free State for the financial support.

\section{References}

1. Silver, S.; Phung, L. T.; Silver, G. Silver as Biocides in Burn and Wound Dressings and Bacterial Resistance to Silver Compounds. J. Ind. Microbiol. Biotechnol. 2006, 33, 627-634. DOI: 10.1007/ s10295-006-0139-7.

2. De Matteis, V.; Cascione, M.; Toma, C.; Leporatti, S. Silver Nanoparticles: Synthetic Routes, in Vitro Toxicity and Theranostic Applications for Cancer Disease. Nanomaterials 2018, 8, 319. DOI: 10.3390/nano8050319. 
3. Asharani, P. V.; Hande, M. P.; Valiyaveettil, S. Anti-Proliferative Activity of Silver Nanoparticles. BMC Cell Biol. 2009, 10, 65. DOI: $10.1186 / 1471-2121-10-65$.

4. Gurunathan, S.; Han, J. W.; Eppakayala, V.; Jeyaraj, M.; Kim, J. H. Cytotoxicity of Biologically Synthesized Silver Nanoparticles in MDA-MB-231 Human Breast Cancer Cells. BioMed Res. Int. 2013, 2013, 1-10. DOI: 10.1155/2013/535796.

5. Urbańska, K.; Pająk, B.; Orzechowski, A.; Sokołowska, J.; Grodzik, M.; Sawosz, E.; Szmidt, M.; Sysa, P. The Effect of Silver Nanoparticles (AgNPs) on Proliferation and Apoptosis of in Ovo Cultured Glioblastoma Multiforme (GBM) Cells. Nanoscale Res. Lett. 2015, 10, 98. DOI: 10.1186/s11671-015-0823-5.

6. Ahamed, M.; AlSalhi, M. S.; Siddiqui, M. K. J. Silver Nanoparticle Applications and Human Health. Clin. Chim. Acta 2010, 411, 1841-1848. DOI: 10.1016/j.cca.2010.08.016.

7. Zhang, X. F.; Liu, Z. G.; Shen, W.; Gurunathan, S. Silver Nanoparticles: synthesis, Characterization, Properties, Applications, and Therapeutic Approaches. Int. J. Mol. Sci. 2016, 17, 1534. DOI: 10.3390/ijms17091534.

8. Reijnders, L. Hazard Reduction in Nanotechnology. J. Ind. Ecol. 2008, 12, 297-306. DOI: 10.1111/j.1530-9290.2008.00049.

9. Kathiravan, V.; Ravi, S.; Ashokkumar, S. Synthesis of Silver Nanoparticles from Melia Dubia Leaf Extract and Their in Vitro Anticancer Activity. Spectrochim. Acta, Part A 2014, 130, 116-121. DOI: 10.1016/j.saa.2014.03.107.

10. Mazid, M.; Khan, T. A.; Mohammad, F. Role of Secondary Metabolites in Defense Mechanisms of Plants. Biol. Med. 2011, 3, 232-249.

11. Ashokkumar, R.; Ramaswamy, M. Phytochemical Screening by FTIR Spectroscopic Analysis of Leaf Extracts of Selected Indian Medicinal Plants. Int. J. Curr. Microbiol. Appl. Sci. 2014, 3, 395-406.

12. Sadeghi, B.; Gholamhoseinpoor, F. A Study on the Stability and Green Synthesis of Silver Nanoparticles Using Ziziphora Tenuior (Zt) Extract at Room Temperature. Spectrochim. Acta Part A 2015, 134, 310-315. DOI: 10.1016/j.saa.2014.06.046.

13. Mohapatra, B.; Kuriakose, S.; Mohapatra, S. Rapid Green Synthesis of Silver Nanoparticles and Nanorods Using Piper Nigrum Extract. J. Alloys Compd. 2015, 637, 119-126. DOI: 10. 1016/j.jallcom.2015.02.206.

14. Amin, M.; Anwar, F.; Janjua, M. R. S. A.; Iqbal, M. A.; Rashid, U. Green Synthesis of Silver Nanoparticles through Reduction with Solanum Xanthocarpum L. berry Extract: characterization, Antimicrobial and Urease Inhibitory Activities against Helicobacter pylori. Int. J. Mol. Sci. 2012, 13, 9923-9941. DOI: 10.3390/ijms13089923.

15. Roodt, V. Trees and Shrubs of the Okavango Delta: medicinal Uses and Nutritional Value. Shell Field Guide Series: Part I. Gaborone: Shell Oil Botswana 1998.

16. Tedder, M. J.; Kirkman, K. P.; Morris, C. D.; Trollope, W. S.; Bonyongo, M. C. Determinants of the Occurrence of a Native Encroacher Species, Pechuel-Loeschea Leubnitziae (Wild Sage), in the Eastern Okavango Delta, Botswana. Afr. J Range Forage Sci. 2015, 32, 253-259. DOI: 10.2989/10220119.2015.1005668.

17. Chinsembu, K. C. Plants as Antimalarial Agents in Sub-Saharan Africa. Acta Trop. 2015, 152, 32-48. DOI: 10.1016/j.actatropica. 2015.08.009.
18. Dushimemaria, F.; Mumbengegwi, D. R. Proposition of a LowCost Field Assay to Determine Antiproliferative Properties of Indigenous Plants Using Dugesia Dorotocephala (Brown Planaria). Sci. Res. Essays 2015, 10, 144-149. DOI: 10.5897/ SRE2014.6112.

19. Van Damme, P.; Van Den Eynden, V.; Vernemmen, P. Plant Uses by the Topnaar of the Kuiseb Valley Namib Desert. AF. 1922, 8, 223-252. DOI: 10.21825/af.v8i3-4.5847.

20. Von Koenen, E. Medicinal, Poisonous, and Edible Plants in Namibia. Windhoek, Namibia: Klaus Hess Publishers 2001.

21. Hedimbi, M.; Kaputjaza, D. K.; Hans, R. H.; Mumbengegwi, D. R.; Bock, R. Phytochemical Analysis and Antimicrobial Screening Crude Extracts from Pechuel-Loeschea Leubnitziae (Kuntze) O. (Asteraceae). Journal of Research in Microbes 2012, 1, 039-043.

22. Ndongo, D. Antibacterial, Antioxidant and Phytochemical Investigation of Acacia Arenaria, Aloe Esculenta and PechuelLoeschea Leubnitziae. Doctoral dissertation, University of Namibia, 2017.

23. Kadhila, N. P. Evaluation of Indigenous Namibian Mushrooms and Plants for Antimalarial Properties. Doctoral Dissertation, University of Namibia, 2019.

24. Castangia, I.; Marongiu, F.; Manca, M. L.; Pompei, R.; Angius, F.; Ardu, A.; Fadda, A. M.; Manconi, M.; Ennas, G. Combination of Grape Extract-Silver Nanoparticles and Liposomes: A Totally Green Approach. Eur. J. Pharm. Sci. 2017, 97, 62-69. DOI: 10.1016/j.ejps.2016.11.006.

25. Mallikarjuna, K.; Narasimha, G.; Dillip, G. R.; Praveen, B.; Shreedhar, B.; Lakshmi, C. S.; Reddy, B. V. S.; Raju, B. D. P. Green Synthesis of Silver Nanoparticles Using Ocimum Leaf Extract and Their Characterization. Digest Journal of Nanomaterials and Biostructures 2011, 6, 181-186.

26. Chastain, J. Handbook of X-Ray Photoelectron Spectroscopy. Eden Prairie, MN: Perkin-Elmer Corporation 1992, 40, 221.

27. Andreescu, D.; Eastman, C.; Balantrapu, K.; Goia, D. V. A Simple Route for Manufacturing Highly Dispersed Silver Nanoparticles. J. Mater. Res. 2007, 22, 2488-2496. DOI: 10.1557/ jmr.2007.0308

28. Kumar, G.; Karthik, L.; Rao, K. B. Phytochemical Composition and in Vitro Antimicrobial Activity of Bauhinia Racemosa Lamk (Caesalpiniaceae). Int. J. Pharm. Sci. Res. 2010, 1, 51.

29. Lu, J.; Bravo-Suárez, J. J.; Takahashi, A.; Haruta, M.; Oyama, S. T. In Situ UV-Vis Studies of the Effect of Particle Size on the Epoxidation of Ethylene and Propylene on Supported Silver Catalysts with Molecular Oxygen. J. Catal. 2005, 232, 85-95. DOI: $10.1016 /$ j.jcat.2005.02.013.

30. Li, K.; Jia, X.; Tang, A.; Zhu, X.; Meng, H.; Wang, Y. Preparation of Spherical and Triangular Silver Nanoparticles by a Convenient Method. Integr. Ferroelectr. 2012, 136, 9-14. DOI: 10.1080/10584587.2012.686405.

31. Mariri, N. G. In Vitro Evaluation of the Bioactivity of Gnidia Polycephala and Senecio Serratuloides., 2017. Master's Dissertation, Bloemfontein: Central University of Technology, Free State. 